\title{
Study of ovarian cancer at a tertiary care centre
}

\author{
Jayashree Mulik, Swapnil Khadse*
}

Department of Obstetrics and Gynecology, Government Medical College and Hospital, Nagpur, Maharashtra, India

Received: 19 May 2020

Accepted: 29 June 2020

\section{*Correspondence:}

Dr. Swapnil Khadse,

E-mail: drswapnilkhadse@ rediffmail.com

Copyright: () the author(s), publisher and licensee Medip Academy. This is an open-access article distributed under the terms of the Creative Commons Attribution Non-Commercial License, which permits unrestricted non-commercial use, distribution, and reproduction in any medium, provided the original work is properly cited.

\section{ABSTRACT}

Background: Despite major advances in case management, ovarian cancer continues to have the highest case fatality rate of all gynaecologic malignancies. There is paucity of meaningful screening and diagnostic protocols. Present study was planned with the objective of assessment of the prevalence of ovarian cancer and the associated risk factors at a tertiary care centre.

Methods: The present prevalence study was conducted at a tertiary care government hospital and entailed analysis of data of 73 patients of ovarian cancer. All the participants were subjected to comprehensive history taking, followed by general, systemic, per-speculum and per-vaginal examination. Serum tumour markers of the patients were assessed. Imaging studies including ultrasound, CT or MRI abdomen/pelvis were done as per need. Final diagnosis was confirmed on histopathology and the cases were classified according to histological classification of World Health Organization.

Results: Majority $(41,56.2 \%)$ were aged more than 45 years and above, most of them with one to two previous issues (64.3\%). The disease was observed to be more common in postmenopausal women $(65,89 \%)$. Three fourth participants had negative family history of ovarian or breast cancer. Out of 73 patients, 31 had value of CA 125 between 150-400 U/mL and 42 had values $>400 \mathrm{U} / \mathrm{mL}$. Epithelial ovarian cancer (serous- 33, 45.2\%, mucinous- 18, $24.7 \%$ ) was observed to be the commonest histological type.

Conclusions: To diagnose ovarian tumours early using multipronged approach with focussed risk factor identification and screening with CA-125 is very important and is strongly recommended.

Keywords: Mucinous, Ovarian cancer, Serous, Tumour marker, CA-125

\section{INTRODUCTION}

Ovarian malignancies are a group of diseases with varying clinical and biological behaviour. Ovarian cancer is the fourth most common cancer among women worldwide and second most common genital malignancy in India. ${ }^{1,2}$ It is the leading cause of mortality among all cancers of female genital tract in countries where effective cervical cancer screening program exists. This high mortality is explained by the fact that most of the cases present only when the disease spreads outside the ovary. There are marked differences in survival among patients depending on factors such as age, cancer stage, and tissue type. ${ }^{3}$ Other factors such as increasing parity, use of oral contraceptives pills and breast feeding appear to have protective effect; while low parity/subfertility, use of fertility drugs and genetic factors apparently increase the risk. ${ }^{4,5}$

There is paucity of any proper screening and diagnostic protocols till date for this lethal disease in spite of enormous advancement in the treatment in its late stage. A thorough clinical examination with the aid of imaging techniques helps determine the extent of the disease preoperatively and subsequent planning of treatment. But despite major advances made in case management, ovarian cancer continues to have the highest case fatality rate of all gynaecologic malignancies. ${ }^{1,6}$ During past 30 
years, limited progress has been made in improving the survival rate of patients with late-stage ovarian cancer.

With this research lacuna in mind, the present study was planned with the objective of assessment of the prevalence of ovarian cancer and the associated risk factors at a tertiary care centre.

\section{METHODS}

The present descriptive cross-sectional study was conducted over 22 months (January 2018 to October 2019) at a tertiary care government teaching hospital in Central India by the department of obstetrics and gynecology at the tertiary care centre. Institutional ethics committee approval was obtained prior to start of the study and written informed consent was obtained from all the patients before enrollment.

All the diagnosed cases of ovarian cancer who had visited the study centre during study period constituted the study population. Following selection criteria were employed before participation in the study.

\section{Inclusion criteria}

- All patients of ovarian cancer consulted gynecology OPD at tertiary health centre

- All patient of ovarian cancer admitted in gynecology wards of tertiary health centre

- All patients with ovarian cancer referred to tertiary health centre.

\section{Exclusion criteria}

- Patients with benign ovarian tumour

- Patients with any other genital malignancy e.g. Ca cervix, $\mathrm{Ca}$ endometrium

- Those refusing to give consent.

A total of 73 patients were thus found eligible and enrolled for the study. All the participants were subjected to comprehensive history taking, including age, place of residence, socioeconomic status, history of infertility and use of any infertility drugs, lactation history, contraceptive use, years of ovulation, family history, diet history, elaborate menstrual and obstetric history followed by detailed medical history including that of liver disorder, thyroid disorder, renal disorder and bleeding tendencies etc. History taking was followed by general and systemic examination, with emphasis on per abdomen examination. Per speculum examination was conducted to rule out any cervical polyp, cervical erosion, malignancy or pathological discharge. Detailed per vaginal examination was conducted to check upon size, position and mobility of uterus and fornix examination to rule out adnexal mass or tenderness. Size, consistency, mobility of any mass present was documented. A provisional diagnosis was made based on signs, symptoms and examination findings.
Routine haematological and biochemical investigation were done. Serum tumour markers including CA-125, CEA, HCG, and AFP of the patients were assessed and values documented with appropriate cut-offs. Imaging studies including ultrasound, CT or MRI abdomen/pelvis were done as required to aid in diagnosis or for additional information to detect stage of the disease to aid in planning of treatment. Final diagnosis was confirmed on histopathology and ovarian cancer were classified according to histological classification of World Health Organization (WHO). ${ }^{7}$ The average time interval between admission and laparotomy was 1-2 weeks. For emergency cases who presented with feature of acute abdomen the time interval was 6-24 hours.

\section{Statistical analysis}

All the data was entered into a Microsoft excel sheet and analyzed by using stat disc free software version 13.0.1. Chi-square test and Fishers exact test were used and $\mathrm{p}<0.05$ was considered statistically significant.

\section{RESUTS}

The present prevalence study was conducted at a tertiary care hospital and entailed analysis of data of 73 patients of ovarian cancer. Majority of the patients were in the group of $45-54$ years $(20,27.4 \%)$ or 55 years and above $(21,28.8 \%)$. Studying the obstetric history revealed higher prevalence of ovarian cancer in women with one to two previous issues (64.3\%) (Table 1).

Table 1: Age and obstetric history distribution amongst participants $(n=73)$.

\begin{tabular}{|lll|}
\hline Variable & No of patients $(\mathbf{n}=\mathbf{7 3})$ & Percentage \\
\hline Age in years & & \\
\hline 15 to 24 & 5 & $6.8 \%$ \\
\hline 25 to 34 & 12 & $16.4 \%$ \\
\hline 35 to 44 & 15 & $20.5 \%$ \\
\hline 45 to 54 & 20 & $27.4 \%$ \\
\hline$>55$ & 21 & $28.8 \%$ \\
\hline Parity & & \\
\hline Nulliparous & 1 & $1.4 \%$ \\
\hline $1-2$ & 47 & $64.4 \%$ \\
\hline $3-4$ & 19 & $26 \%$ \\
\hline$>4$ & 6 & $8.2 \%$ \\
\hline
\end{tabular}

Mostly women with age at menarche between 13-14 years were found predisposed for ovarian cancer. Out of 73 cases, $22(30.1 \%)$ and $27(37.0 \%)$ patients had menarche at 13 years and 14 years of age respectively. Study of distribution of patients according to menstrual history revealed ovarian cancer to be more common in postmenopausal women $(65,89 \%)$ (Table 2). Out of 73 participants, $60(82.2 \%)$ did not use oral contraceptive pills and tubal ligation was not done in 58 patients 
(79.4\%). Fifty-five patients $(75.3 \%)$ were having negative family history and 18 patients (24.7\%) were having positive family history of ovarian or breast cancer. Out of 73 patients, 35 were overweight $(47.9 \%), 15$ $(20.5 \%)$ were obese and 23 patients $(31.5 \%)$ were normal.

Table 2: Distribution of cases according to age at menarche and menstrual history $(n=73)$.

\begin{tabular}{|lll|}
\hline $\begin{array}{l}\text { Variable } \\
\text { Age at menarche (Years) }\end{array}$ & Percentage \\
\hline 12 & 1 & $1.4 \%$ \\
\hline 13 & 22 & $30.1 \%$ \\
\hline 14 & 27 & $37.0 \%$ \\
\hline 15 & 16 & $22.0 \%$ \\
\hline 16 & 7 & $9.5 \%$ \\
\hline Menstrual history & & \\
\hline Postmenopausal & 65 & $89 \%$ \\
\hline Premenopausal & 08 & $11 \%$ \\
\hline
\end{tabular}

Table 3: Distribution of patients according to CA-125 and Histopathology report.

\begin{tabular}{|llll|}
\hline $\begin{array}{l}\text { Histopathology } \\
\text { Report }\end{array}$ & $\begin{array}{l}\text { CA-125 levels } \\
\text { U/ml }\end{array}$ & $\begin{array}{l}\mathbf{> 4 0 0} \\
\mathbf{U} / \mathbf{m l}\end{array}$ & $\begin{array}{l}\text { Total } \\
(\%)\end{array}$ \\
\hline $\begin{array}{l}\text { Adenocarcinoma of } \\
\text { ovary }\end{array}$ & 3 & 4 & $7(9.6 \%)$ \\
\hline Dysgerminoma & 0 & 1 & $1(1.4 \%)$ \\
\hline $\begin{array}{l}\text { Immature Teratoma } \\
\text { of ovary }\end{array}$ & 0 & 1 & $1(1.4 \%)$ \\
\hline $\begin{array}{l}\text { Mucinous epithelial } \\
\text { carcinoma of ovary }\end{array}$ & 11 & 7 & $\begin{array}{l}18 \\
(24.7 \%)\end{array}$ \\
\hline $\begin{array}{l}\text { Papillary epithelial } \\
\text { carcinoma of ovary }\end{array}$ & 5 & 5 & $\begin{array}{l}10 \\
(13.6 \%)\end{array}$ \\
\hline $\begin{array}{l}\text { Pseudomyxoma } \\
\text { Peritonei }\end{array}$ & 1 & 0 & $1(1.4 \%)$ \\
\hline $\begin{array}{l}\text { Serous epithelial } \\
\text { carcinoma of ovary }\end{array}$ & 21 & 12 & $\begin{array}{l}33 \\
(45.2 \%)\end{array}$ \\
\hline $\begin{array}{l}\text { Surface epithelial } \\
\text { carcinoma of ovary }\end{array}$ & 1 & 1 & $2(2.7 \%)$ \\
\hline \begin{tabular}{l} 
Total \\
\hline
\end{tabular} & 31 & 42 & $\begin{array}{l}73 \\
(100.0 \%)\end{array}$ \\
\hline
\end{tabular}

The serum CA-125 assessment was undertaken for all the participants and values lower than $35 \mathrm{U} / \mathrm{mL}$ were considered as normal. All the participants had values greater than $35 \mathrm{U} / \mathrm{mL}$ in the present study. Out of 73 patients, 31 patients had value of CA 125 between 150$400 \mathrm{U} / \mathrm{mL}$ and 42 patients had values $>400 \mathrm{U} / \mathrm{mL}$. Further histopathological classification of the cases revealed epithelial ovarian cancer to be the most common among the all ovarian cancer types. Among epithelial ovarian cancer types, serous epithelial carcinoma of ovary $(33,45.2 \%)$ was the commonest type in the study, followed by mucinous epithelial ovarian cancer (18, $24.7 \%$ ) (Table 3).

\section{DISCUSSION}

Ovarian cancers are one of the most fatal cancer types and one with the highest case fatality rate amongst gynecological malignancies. ${ }^{1,6}$ Risk factor identification, timely and effective screening leading to early detection is the key in case of ovarian cancers. The present study was conducted with focus on the assessment of prevalence of ovarian cancer and the associated risk factors.

A total of 73 cases of ovarian cancer were studied as a part of this study. Majority of the patients were middle aged or elderly, which is in line with the earlier identified age groups for the disease. ${ }^{8-10}$ Higher prevalence of ovarian cancer observed in women with one to two previous issues $(64.3 \%)$ was also similar to the previous researchers' observations. ${ }^{9,10}$ Mostly those with age at menarche between 13-14 years were found more prone for ovarian cancer in the present study. In the study carried by Momenimovahed et al, the results showed positive relationship between early onset of menarche and risk of ovarian cancer. ${ }^{11}$ But other researchers reported age of menarche to be having no effect on the risk of ovarian cancer. ${ }^{8-10}$ The observation of present study that ovarian cancers are more common in postmenopausal women $(65,89 \%)$ also sits well with most of the available evidence. ${ }^{8-11}$

Majority of patients (82.2\%) in the present study did not use oral contraceptive pills. This is in line with available literature, suggesting lack of protection that could have been there with the OC pills usage. In the study carried by Wernli KJ et al, the authors have shown that the use of oral contraceptives reduces a woman's risk for epithelial ovarian cancer. ${ }^{12}$ Whittemore and associates, in a collaborative analysis of 12 case-control studies, had also observed that women who used oral contraceptives had a RR of 0.66 (95\% CI 0.55-0.78) as compared with population controls. ${ }^{13}$

The data from their study also support the hypothesis that long-term oral contraceptive use reduces risk of ovarian cancer among women who carry mutations of BRCA1 or BRCA2. The risk decreased by a mean of $5 \%$ with each year of use (p- 0.01) and use for 6 or more years was associated with an odds ratio of 0.62 (0.35-1.09). ${ }^{13}$ With respect to tubal ligation (TL), the available evidence suggests significant protective effect, which is in contrast with findings of present study where majority $(79.4 \%)$ did not undergo TL.

In a prospective study of 121,700 registered nurses in the Nurses' health study with 12-year follow-up, a strong inverse relationship between bilateral TL and ovarian cancer was reported (RR 0.33; 95\% CI 0.16-0.64). ${ }^{14}$ Similarly, in a case-control study of 300 cases and 606 controls, Cornelison and co-workers showed a 50\% risk reduction in women who had TLs. ${ }^{15}$ The paradoxical 
observation is may be due to smaller sample size in the present study.

Three fourth of the participants were having negative family history of ovarian or breast cancer in the present study, which is much in line with the well-established fact that ovarian cancer runs in families. Hall and associates in 1990 mapped a locus for familial ovarian cancer to the long arm of chromosome 17 in the interval 17q12-21. ${ }^{16}$ This was before the cloning of BRCA1 by Miki and coworkers and of BRCA2 by Wooster et al. ${ }^{17,18}$ Because familial ovarian cancer (site-specific) is thought to be inherited in an autosomal dominant pattern with variable penetrance, sisters and daughters in families with a history of familial ovarian cancer (two or more firstdegree relatives, mother/sister/daughter, who share one half of their genes) may have a $50 \%$ chance of disease development. The positive relationship between overweight/obesity and ovarian cancer occurrence is also in agreement with previously well-established evidence. ${ }^{19}$

Epithelial ovarian cancer was observed to be the commonest amongst the all ovarian cancer on histopathology examination, which is corroborative of available evidence. Basu et al reported $80 \%$ epithelial ovarian tumours among all ovarian malignancies; while in the study by Yogambal et al epithelial tumours were seen in $71.6 \%$ cases. $^{20,21}$ Among various epithelial ovarian cancer types, serous epithelial carcinoma of ovary $(33,45.2 \%)$ was the commonest type followed by mucinous epithelial ovarian cancer $(18,24.7 \%)$, much in line with observations of past researchers. ${ }^{20,21}$ The proportion of ovarian malignancy cases was $12.4 \%$ of all gynecological malignancies (590) during the 22 months period.

The serum CA-125 level is considered an important screening test in case of ovarian cancer. The serum CA125 assessment was undertaken for all the participants and 31 out of 73 patients had values between 150-400 $\mathrm{U} / \mathrm{mL}$ while 42 patients had values $>400 \mathrm{U} / \mathrm{mL}$, much on the expected lines.

CA-125 level is commonly raised in case of nonmucinous serous tumour of ovary and is the most sensitive amongst all the markers available. ${ }^{22}$ In the study carried out by Pradhan et al, CA-125 was the commonest tumour marker seen in $28.75 \%$ participants followed by CEA $(5.83 \%)$ and LDH $(4.58 \%) .{ }^{9}$ In fact, combining the markers has been shown to significantly increase the preoperative sensitivity of detecting early stage disease. ${ }^{23}$

\section{CONCLUSION}

In conclusion, it can be said that it is of paramount importance to diagnose ovarian tumours early and multipronged approach with focussed risk factor identification and screening with CA-125, along with other markers as relevant, will go a long way in achieving the same.
Funding: No funding sources

Conflict of interest: None declared

Ethical approval: The study was approved by the Institutional Ethics Committee

\section{REFERENCES}

1. Jemal A, Siegel R, Ward E, Murray T, Xu J, Thun MJ. Cancer statistics, 2007. Cancer J Clin. 2007;57(1):43-66.

2. Murthy NS, Shalini S, Suman G, Pruthvish S, Mathew A. Changing trends in incidence of ovarian cancer-the Indian scenario. Asian Pac J Cancer Prev. 2009;10(6):1025-30.

3. Ries LA. Ovarian cancer: survival and treatment differences by age. Cancer. 1993;71(S2):524-9.

4. Cramer DW, Hutchison GB, Welch WR, Scully RE, Ryan KJ. Determinants of ovarian cancer risk. I. Reproductive experiences and family History. J National Cancer Inst. 1983;71:711.

5. Cramer DW, Welch WR. Determinants of ovarian cancer risk. II. Inferences regarding pathogenesis. J National Cancer Inst. 1983;71(4):717-21.

6. Lowe KA, Chia VM, Taylor A, O’Malley C, Kelsh M, Mohamed M, et al. An international assessment of ovarian cancer incidence and mortality. Gynecol Oncol. 2013;130(1):107-14.

7. Scully RE. World Health Organization classification and nomenclature of ovarian cancer. Natl Cancer Inst Monogr. 1975;42:5-7.

8. Puri S, Chadha V, Pandey AK. Epidemiology of ovarian tumours in Northern India-A tertiary hospital based study. Indian $\mathbf{J}$ Comm Family Med. 2018;4(2):37.

9. Pradhan HK, Singh P, Ravikumar MS, Gothwal M. Study of risk factors and tumor markers in ovarian malignancy in western part of Odisha: a prospective observational study. Int $\mathbf{J}$ Reprod Contracept Obstet Gynecol. 2018;7(4):1572.

10. Mondal SK, Banyopadhyay R, Nag DR, Roychowdhury S, Mondal PK, Sinha SK. Histologic pattern, bilaterality and clinical evaluation of 957 ovarian neoplasms: a 10-year study in a tertiary hospital of eastern India. J Cancer Res Therapeut. 2011;7(4):433.

11. Momenimovahed Z, Tiznobaik A, Taheri S, Salehiniya H. Ovarian cancer in the world: epidemiology and risk factors. Int J Women's Health. 2019;11:287.

12. Wernli KJ, Newcomb PA, Hampton JM, TrenthamDietz A, Egan KM. Inverse association of NSAID use and ovarian cancer in relation to oral contraceptive use and parity. $\mathrm{Br} \mathrm{J}$ Cancer. 2008;98(11):1781-3.

13. Whittemore AS, Harris R, Ltnyre J. Collaborative ovarian cancer group. Characteristics relating to ovarian cancer risk: collaborative analysis of 12 US case-control studies: IV. The pathogenesis of epithlial ovarian cancer. Am J Epidemiol. 1992;136(10):1212-20. 
14. Rice MS, Hankinson SE, Tworoger SS. Tubal ligation, hysterectomy, unilateral oophorectomy, and risk of ovarian cancer in the Nurses' Health Studies. Fertil Steril. 2014;102(1):192-8.

15. Cornelison TL, Natarajan N, Piver MS, Mettlin CJ. Tubal ligation and the risk of ovarian carcinoma. Cancer Detect Prevent. 1997;21(1):1-6.

16. Hall JM, Friedman L, Guenther C, Lee MK, Weber $\mathrm{JL}$, Black DM, et al. Closing in on a breast cancer gene on chromosome 17q. Am J Human Genet. 1992;50(6):1235.

17. Miki Y, Swensen J, Shattuck-Eidens D, Futreal PA, Harshman K, Tavtigian S, et al. A strong candidate for the breast and ovarian cancer susceptibility gene BRCA1. Sci. 1994:66-71.

18. Wooster R, Bignell G, Lancaster J, Swift S, Seal S, Mangion J, et al. Identification of the breast cancer susceptibility gene BRCA2. Nature. 1995;378(6559):789-92.

19. Nagle CM, Dixon SC, Jensen A, Kjaer SK, Modugno F, DeFazio A, et al. Obesity and survival among women with ovarian cancer: results from the ovarian cancer association consortium. Br J Cancer. 2015;113(5):817-26.
20. Basu P, De P, Mandal S, Ray K, Biswas J. Study of' patterns of care of ovarian cancer patients in a specialized cancer institute in Kolkata, eastern India. Indian J Cancer. 2009;46(1):28.

21. Yogambal M, Arunalatha P, Chandramouleeswari K, Palaniappan V. Ovarian tumours-Incidence and distribution in a tertiary referral center in south India. J Dent Med Sci. 2014;3(2):74-80.

22. Visintin I, Feng Z, Longton G, Ward DC, Alvero $\mathrm{AB}$, Lai Y, et al. Diagnostic markers for early detection of ovarian cancer. Clin Cancer Res. 2008;14(4):1065-72.

23. Woolas RP, Xu FJ, Jacabs IJ, Yu YH, Daly L, Brechuck A, et al. Elevation of multiple serum markers in patients with stage I ovarian cancer. J National Cancer Inst. 1993;85(21):1748-51.

Cite this article as: Mulik J, Khadse S. Study of ovarian cancer at a tertiary care centre. Int J Reprod Contracept Obstet Gynecol 2020;9:3228-32. 